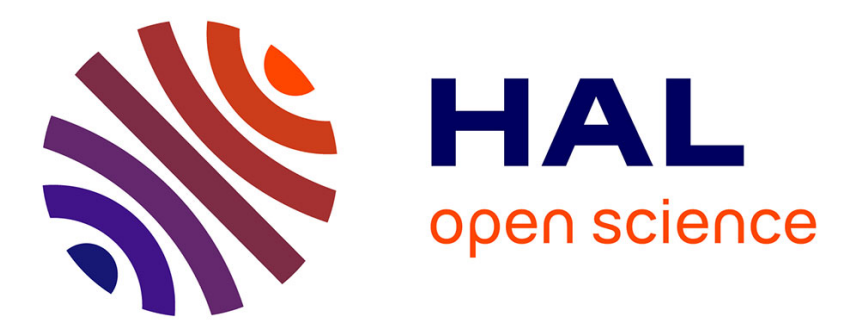

\title{
From IL-15 to IL-33: the never-ending list of new players in inflammation. Is it time to forget the humble Aspirin and move ahead?
}

Fulvio d'Acquisto, Francesco Maione, Magali Pederzoli-Ribeil

\section{To cite this version:}

Fulvio d'Acquisto, Francesco Maione, Magali Pederzoli-Ribeil. From IL-15 to IL-33: the never-ending list of new players in inflammation. Is it time to forget the humble Aspirin and move ahead?. Biochemical Pharmacology, 2009, 79 (4), pp.525. 10.1016/j.bcp.2009.09.015 . hal-00544816

\author{
HAL Id: hal-00544816 \\ https://hal.science/hal-00544816
}

Submitted on 9 Dec 2010

HAL is a multi-disciplinary open access archive for the deposit and dissemination of scientific research documents, whether they are published or not. The documents may come from teaching and research institutions in France or abroad, or from public or private research centers.
L'archive ouverte pluridisciplinaire HAL, est destinée au dépôt et à la diffusion de documents scientifiques de niveau recherche, publiés ou non, émanant des établissements d'enseignement et de recherche français ou étrangers, des laboratoires publics ou privés. 


\section{Accepted Manuscript}

Title: From IL-15 to IL-33: the never-ending list of new players in inflammation. Is it time to forget the humble Aspirin and move ahead?

Authors: Fulvio D'Acquisto, Francesco Maione, Magali Pederzoli-Ribeil

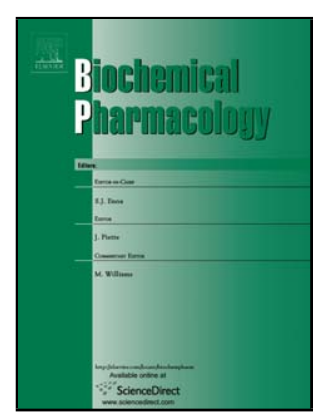

PII: S0006-2952(09)00769-2

DOI: doi:10.1016/j.bcp.2009.09.015

Reference: BCP 10329

To appear in: $\quad B C P$

Received date: $\quad 30-7-2009$

Revised date: $\quad$ 9-9-2009

Accepted date: $\quad$ 10-9-2009

Please cite this article as: D'Acquisto F, Maione F, Pederzoli-Ribeil M, From IL15 to IL-33: the never-ending list of new players in inflammation. Is it time to forget the humble Aspirin and move ahead?, Biochemical Pharmacology (2008), doi:10.1016/j.bcp.2009.09.015

This is a PDF file of an unedited manuscript that has been accepted for publication. As a service to our customers we are providing this early version of the manuscript. The manuscript will undergo copyediting, typesetting, and review of the resulting proof before it is published in its final form. Please note that during the production process errors may be discovered which could affect the content, and all legal disclaimers that apply to the journal pertain. 


\title{
COMMENTARY
}

\section{From IL-15 to IL-33: the never-ending list of new players in inflammation. Is it time to forget the humble Aspirin and move ahead?}

*Fulvio D'Acquisto, Francesco Maione and Magali Pederzoli-Ribeil

\begin{abstract}
William Harvey Research Institute, Queen Mary University of London, Barts and The London Medical School, Charterhouse Square, London EC1M 6BQ, UK.
\end{abstract}

\footnotetext{
*Author for correspondence: Fulvio D'Acquisto, The William Harvey Research Institute, Queen Mary University of London, Barts and The London, Charterhouse Square, London EC1M 6BQ, UK.

Phone: +44-207-882 6081; Fax: +44-207-8826076; e.mail: F.Dacquisto@qmul.ac.uk
}

Key words: Interleukin-15, Interleukin-17, Interleukin-18, Interleukin-21, Interleukin22, Interleukin-27, Interleukin-33; resolution of inflammation; autoimmune diseases, antinflammatory drugs. 


\begin{abstract}
The study of the inflammatory response has seen a tremendous expansion over the last 30 years. Advancements in technology and better knowledge of the ethiopathogenesis of several inflammatory conditions have facilitated this process allowing researchers to almost reach the core of problem. Thus, we now know that inflammation can be manifested in many different ways depending on the context that has elicited it. Viral and infectious, allergic and autoimmune, carcinogenic and resolutive are just a few examples of how inflammation can disguise itself.
\end{abstract}

However, and most intriguingly, it appears that the more we try to discover "an ideal target" and delineate borders for a specific class of inflammatory conditions the more we find similarities, overlaps or often links that we did not predict. These somehow disappointing findings have pushed researchers towards a frantic search for new and more "reliable" targets. As result, we have recently seen a surge of many novel mediators of inflammation. If we just limit our focus to inflammatory cytokines, the main topic of this commentary, the list seems never-ending: IL-15, IL-17, IL-18, IL-21, IL-22, IL-23, IL-27 and IL-33. Are these cytokines destined to supersede prostaglandins and other autacoids for their key role in inflammation? Are we going to see a cheap and effective alternative to Aspirin on the supermarket shelves in the next few years?

Here we summarize the most recent findings on the biological effects of these new inflammatory cytokines and discuss how these discoveries might influence our current view on therapeutic approaches to treat inflammation. 
Scientists working on inflammation would agree with us that this field of research has seen a tremendous expansion over the last 30 years. This could be explained in many different ways: surely, a better knowledge of the molecular mechanisms underlying the complex and different inflammatory diseases has provided us with a number of novel mediators and signalling pathways, all seeming to play pivotal roles in these processes. These findings are supported by a number of convincing and technically sophisticated evidences, including those generated with knockout and transgenic mice or produced after gene therapy protocols. However, we should not forget that "inflammation" is a generic term to describe a phenomenon that comes about in many different flavours depending on the context where it has developed, the time point we are investigating and the inflammatory stimuli we are using. More importantly, one aspect that we believe is fundamental for biochemical pharmacologists is to determine how these information can be translated into clinical practice and whether these new targets might be of "general use" or should be considered for "disease-tailored" therapies.

First, however, we should be more careful in defining inflammation in such a generic way and possibly go back in time to a more clear distinction between acute and chronic inflammation existed. Further attention should also be given to another important processes that have been recently described as para-inflammation. In this regard, in one of his excellent and enlightening reviews, Ruslan Medzhitov provided a clear distinction between classical instigators of inflammation such as infection and tissue injury and alternative inducers such as tissue stress and malfunction that similarly induce an adaptive immune response called para-inflammation [1]. Most interestingly, what we believe is now becoming clear is that lack of homeostatic control over the initial phase of the inflammatory response opens the doors to autoimmune diseases [2]. In fact, whenever an active resolutive phase of the immune response fails to take place, then chronic inflammation follows and a completely new set of mediators enters in action [3]. Consistent with this, there is a consensus among the scientific community that the persistent presence of chronic inflammation might be the initial thread that ultimately leads to autoimmunity [4]. 
A large variety of stimuli induce IL-15 expression and/or release including lipopolysaccharide and other bacterial products, fungi, viruses and double-stranded RNA [8]. The mature 114 amino acid biologically active form of IL-15 derives from two different mRNA isoforms encoding for two IL-15 precursor proteins with either a long or short $\mathrm{N}$-terminus $[9,10]$. These $\mathrm{N}$-terminal sequences, along with other posttranslational modifications, influence the limited secretion of IL-15 [11]. These control mechanisms are in fact responsible for the scarce release of this cytokine in the extracellular space, explaining the difficulties encountered for the detection of IL-15. In addition, some interesting studies have shown IL-15 to be highly expressed on the cell surface [12] providing further evidence about the different biological role compared to IL-2 and a possible explanation for the lack of detection in the culture supernatants.

In vivo studies using mice overexpressing IL-15, IL-15 knock-out or IL-15R $\alpha$ knock-out mice have shown that this cytokine plays an important role in the development of NK 
cells, intestinal intraepithelial lymphocytes (i-IELs), and $\mathrm{NK} 1^{+} \mathrm{T}$ cells (NK-T cells) [13, 14]. This suggests that IL-15 has an important role in the innate and mucosal immune response and that drugs targeting this cytokine might be particularly useful for the treatment of diseases characterized by mucosal inflammation such as colitis and inflammatory bowel disease. However, the biological functions of IL-15 are not only restricted to these pathologies since other studies have demonstrated that this cytokine is a potent chemoattractant for T cells [15] and neutrophils [16], two cell types involved in a wide variety of inflammatory response. Consistent with this, several studies have associated IL-15 with a number of autoimmune diseases such as psoriasis, multiple sclerosis and rheumatoid arthritis $[17,18]$.

\section{Interleukin-17}

If we had to label one of these novel cytokines a "superstar", this would be, without any doubt, IL-17. Indeed, it is fair to say that the discovery of this cytokine and its biological function has revolutionized the field of immunology and has completely changed the way we look at many immune-mediated inflammatory pathologies. The main reason for so much popularity compared to the other cytokines is the identification of a particular subset of $\mathrm{T}$ helper cells that specifically produce this cytokine and are for this reason named Th17 cells.

The discovery of this subset of T cells has changed a long known paradigm that classified cell mediated immune response in Th1 or Th2 depending on the type of pathogen causing the immune reaction, being intracellular for Th1 and extracellular for Th2. Th17 cells have gained their unique position in this scenario as cells that defend against extracellular bacteria and fungi. Most importantly, these cells have also been identified as key players in the development of many autoimmune diseases as we will discuss later $[19,20]$.

The most studied members of the IL-17 family (six members in total) are IL-17A and F. Originally named cytotoxic T-lymphocyte-associated antigen 8 (CTL8), IL-17A is a 155 amino acid protein that functions as a homodimer that forms via two sulphidrylic residues. Among the other 5 members, $\mathrm{IL}-17 \mathrm{~F}$ is the one that shares the highest 

functions of IL-17 have been "indirectly" attributed to studying the modulation of Th17 cell development or the expression of the IL-17R. Clearly, although these studies provide very important information regarding IL-17 biology, we should not forget that Th17 cells produce cytokines other than IL-17 (such as IL-21 or IL-22) and that the complex cross talk between different inflammatory mediators present in the inflamed tissues might have contributed to the effects that have been observed and reported.

The cloning and availability of recombinant IL-17A has allowed a number of studies on its inflammatory properties in vitro and in vivo. One of the main cellular targets of IL17A is the neutrophil. Injection of IL-17 in different tissues or incubation of epithelial cells with this cytokine increases the local production of chemokines such as IL-8, monocyte chemoattractant protein-1 (MCP-1) and Gro- $\alpha$ [24]. Systemic injection or adenovirus-mediated gene transfer of IL-17 resulted in dramatic effects on in vivo granulopoiesis with a significant increase (five folds) in the peripheral white blood count and in particular a 10-fold rise in the absolute neutrophil count [25]. In our recent study we have shown that IL-17 per se sustains rather than induces inflammation amplifying the inflammatory response induced by a pre-existing tissue injury [26]. These effects 

arthritis joint. Other effects of IL-17 include stimulation of the production of the hematopoietic cytokines granulocyte colony stimulating factor (G-CSF) and granulocyte macrophage (GM)-CSF, that promote the expansion of cells of myeloid lineages, or other inflammatory mediators such as IL-1, IL-6, TNF- $\alpha$ and PGE 2 [21, 22, 24].

As mentioned above, the majority of information of in vivo IL-17 biology derives from the study of Th17 cells and their role in the development of a wide range of autoimmune diseases. These include rheumatoid arthritis, multiple sclerosis, asthma, and inflammatory bowel disease to name just a few [27, 28]. However, more recent studies suggest that scientists have "rushed to judge" the role of Th17 cells in chronic autoimmune diseases [29] and that, as is often the case, these cells might not be solely responsible for autoimmunity.

\section{Interleukin-18}

Contrary to the other two cytokines described before, IL-18 belongs to the IL-1 family of cytokines and it was initially identified as a factor produced by IFN- $\gamma$ stimulated macrophages. The regulation of IL-18 production is similar to IL-15. The cytokine is constitutively expressed as a pro-form of $22 \mathrm{kDa}$ and its $18 \mathrm{kDa}$ active form released after the action of caspase-1 [30]. A unique feature of IL-18 is its regulation by a "carrier" or decoy receptor like molecule: the IL-18 binding protein (IL-18BP). This protein contributes significantly to the manifestation of the biological effects of IL-18 since it acts as a naturally occurring antagonist, and most importantly, it is upregulated by IL-18 inducing stimuli as part of a negative feedback loop [31, 32]. Consistent with these findings, IL-18BP transgenic mice were able to completely neutralize IFN- $\gamma$ inducing activity of exogenously administered IL-18 and functionally protected against acute ischemic kidney injury or concanavalin A (ConA) induced hepatotoxicity [33].

IL-18 biological functions are both receptor dependent and independent. Binding of IL18 to IL-18R $\alpha$ leads to the formation of a complex with IL-18R $\beta$ that in turn recruits a 

activation of nuclear factor $\kappa \mathrm{B}(\mathrm{NF}-\kappa \mathrm{B})$, c-Jun N-terminal kinase (JNK) and p38 mitogen activated protein kinase (MAPK) [34, 35]. However, comparison of IL-18 and IL$18 \mathrm{R} \alpha$ knock out mice showed a different phenotype when used in mouse models of autoimmune diseases. In fact, it has been shown that IL-18 deficient mice are susceptible to experimental autoimmune encephalomyelitis while IL-18R $\alpha$ knock out mice are resistant to this disease [36]. Similar opposite responses were observed in a mouse model of allograft rejection suggesting that IL-18 mediated antinflammatory effects might be independent of IL-18R $\alpha$ [37]. Alternatively, ligands other than IL-18 could activate IL$18 \mathrm{R} \alpha$.

Indeed, IL-18 has multiple roles potentially impacting both innate and adaptive immune responses since IL-18R $\alpha$ is expressed in neutrophils, macrophages, basophils, mast cells, naïve $\mathrm{T}$ cells, Th1 cells and $\mathrm{B}$ cells. In addition, this receptor is also expressed in a variety of non-immune cells including endothelial cells, smooth muscle cells, epithelial cells, synovial fibroblasts and chondrocytes [38, 39]. It is foreseeable that several new biological properties will be described for this cytokine in the years to come.

Activated monocytes and macrophages are the main cellular source of IL-18. However, a robust IL-18 production can be obtained following stimulation with microbial products that cause the activation of caspase-1. This large release of IL-18 has been reported to be important for the clearance of intracellular pathogens via activation of Th1 cells [40] and viruses via stimulation of CD8 cytotoxic T cells [41]. Interestingly, IL-18 has also a role in the Th2 immune response since it enhances IL-13 production by $\mathrm{T}$ and NK cells when combined with IL-2 [42] and induces the secretion of IL-4, IL-5 and IL-10 in vivo in mouse models of disease [43-45]. Consistent with these observations IL-18 transgenic mice have been shown to produce high levels of both Th1 and Th2 cytokines [46].

Several clinical and experimental studies have shown the clinical relevance of IL-18 in regulating the inflammatory response in vivo. In fact, this cytokine has been detected in 
inflammatory fluids/tissues of several autoimmune diseases such as the cerebrospinal fluids of multiple sclerosis, the synovium of rheumatoid arthritis patients, the inflamed mucosa of Crohn's disease, psoriatic plaques and the atheroma of atherosclerotic patients [47]. This large body of evidences for the pathogenic potential of IL-18 in autoimmune diseases have prompted the development of different therapeutic strategies targeting this cytokine. These include the use of neutralizing antibodies, soluble receptors or inhibitors of IL-18 processing by caspase-1. Many of these have been proved effective in mouse models of chronic inflammatory diseases such as collagen-induced arthritis and are now undergoing clinical trials $[48,49]$.

\section{Interleukin-21}

IL-21 is the most recent addition to the common $\gamma$ chain family of cytokines that comprises IL-2, IL-4, IL-7, IL-9 and IL-15. It was "indirectly" discovered after screening the supernatants of more than 100 primary and immortalized cell lines for a factor that would induce the proliferation of BaF3 cells stably expressing full-length IL-21 receptor (IL-21R) [50-52]. The IL-21R $\alpha$ chain (IL-21R, also termed NILR for novel Interleukin receptor) forms a complex with the common cytokine receptor $\gamma$ chain and this is required for full IL-21 signalling. In fact, although IL-21 is capable of binding IL-21R $\alpha$ chain alone, it has been shown that cells lacking the common cytokine receptor $\gamma$ chain are deficient in IL-21-induced signalling. Depending on the cell type, IL-21R can activate Jak1/Jak3 and in turn STAT1, STAT3, STAT4 and STAT5 signalling pathways. IL-21R is expressed in spleen, thymus, natural killer (NK), T and B cells, dendritic cells macrophages and keratinocytes and the effects of IL-21 seems to be dependent on the cell type and the differentiation or activation status of each cell type [53].

The sequence of the human IL-21 cDNA contains an open reading frame that encodes a polypeptide precursor of 162 amino acids while the mature form has a molecular weight of $15 \mathrm{kDa}$ and consists of a 131 amino acid four-helix-bundle cytokine domain with highest sequence and structural homology to IL-2, IL-4, and IL-15 proteins [50]. In contrast to the wide expression of IL-21R in immune cells, IL-21 is very abundant in activated CD4 T cells but not in CD8 T cells, B cells, myeloid DCs and monocytes. 
Further analyses have initially shown that IL-21 is selectively expressed in Th2 cells and is strongly induced in the secondary Th2 response. Consistent with this, infection of IL21R deficient mice with Schistosoma mansoni parasites resulted in reduced Th2 response in vivo [54]. Interestingly, however, IL-21 knock out CD4 T cells differentiated in vitro showed no differences in Th1 or Th2 but a reduced ability to differentiate in Th17 cells [55]. In addition, the latter have also been shown to produce more IL-21 than Th1 or Th2 cells [56].

IL-21 has pleiotropic effects on a variety of immune cells. This cytokine is well known for its role in the proliferation and survival of B cells as well as their differentiation in plasma cells. Overexpression of this cytokine in vivo or by hydrodynamic transfection in mice caused an increase in the number of immature transitional and memory B cells accompanied by increased serum levels of $\operatorname{IgG}$ and $\operatorname{IgM}$ [57]. Different results were obtained in vitro where IL-21 seems to play either an inhibitory or a promoting effect on B cell proliferation depending on the type of stimuli used to activate the cells $[58,59]$.

Being part of the same family as IL-4 and IL-15, IL-21 was expected to influence DC cell function and differentiation. Indeed, IL-4 and IL-15 are well known for their ability to promote DC development in vitro in presence of granulocyte-macrophage colony stimulating factor (GM-CSF). Unlike its siblings, IL-21 inhibits the functional maturation of DC inducing a reduced expression of MHC II and increased antigen uptake, common features of immature DC. This inhibitory effect was observed not only during the differentiation of DC, but also when IL-21 was added to DC stimulated with LPS [60].

The combination of IL-21 together with TGF- $\beta$ induces the differentiation of CD4 cells towards Th17 cells, while suppressing the generation of FoxP3+ regulatory T cells (Treg) revealing a negative modulatory role of this cytokine on Treg development [61]. In CD8 T cells, IL-21 acts synergistically with IL-15 or IL-7 to induce proliferation of naïve and memory CD8 T cells [62]. Other studies have also shown that IL-21 can increase CD8 T cell antitumor functions and perforin expression in CD8 cells from HIV infected patients [63]. 
Other cells influenced by IL-21 are NK cells. In this context, IL-21 promotes a more mature state and full effector function when this cytokine was added together with IL-15 in vitro during the expansion and differentiation from CD34+ NK progenitor cells [64]. Interestingly, IL-21 has also been shown to reduce the viability of NK cells while boosting their effector functions suggesting that this cytokine induces a transient and potent activation of these cells that in turn leads to their apoptosis [65].

Several recent studies have addressed the suitability of IL-21 targeting for the treatment of autoimmune chronic diseases. Not surprisingly, IL-21 blocking agents such as IL-21RFc fusion proteins have been shown a partial success in a model of SLE, the MRL-lpr mice [66], with a significant benefit in the mouse models of RA: the collagen-induced arthritis and the adjuvant induced arthritis [67, 68]. This complex nature of IL-21 emerges also in EAE where administration of the recombinant cytokine at the onset of disease exacerbates pathology symptoms with similar effects being observed after administration of IL-21 blocking agents too [69].

\section{Interleukin-22}

This cytokine belongs to the IL-10 family members with which it shares a homology of $22 \%$. First identified as "IL-10-related T cell derived inducible factor", it was discovered first in mice and thereafter in human where it is located on chromosome $12 \mathrm{q} 15$ in close proximity to other IL-10 family members such as IL-19, IL-20 and IL-24. At variance from IL-10, IL-22 can function as monomer by binding to IL-22 receptor 1 (IL-22R1) or to a dimer composed of IL-22R1 and IL-10R2 receptor chains. Like in the case of IL-18, this signalling pathway is antagonized and regulated by IL-22 binding protein (IL-22BP) which function is to block IL-22 binding to IL-22R, thanks to shared sequence similarity with an extracellular region of IL-22R1 (sIL-22R1) [70-72].

IL-22R and IL-10R share a common $\beta$ chain (IL-10R $\beta$ ) that in the latter case heterodimerizes with IL-10R $\alpha$ to form the IL-10R. Interestingly, the expression of these two receptors seems to be mutually exclusive with IL-22R being primarily expressed on 

activation of many signalling pathways including STAT1, STAT3, MAP kinases and Akt [73].

Cells of both adaptive (CD4 and CD8 T cells, NKT cells and $\gamma \delta \mathrm{T}$ cells) and innate (mast cells, NK and CD11c+ cells) immune systems express and release IL-22 upon activation. Stimulation of $\mathrm{T}$ cells with a variety of agents including IL-9, IL-12, anti-CD3/CD28 or anti-CD3+ ICAM causes a strong upregulation of this cytokine. However, IL-22 was initially described as Th1, but not Th2 cell, produced cytokine and is now best known as a key Th17-derived effector molecule together with IL-17 [72, 74]. Consistent with these observations, IL-22 expression has been found to be markedly upregulated in several autoimmune diseases. More recent studies in this context have also provided novel information regarding the modulation of IL-22 expression. In particular, it has been suggested that while IL-17A expression requires the presence of both TGF- $\beta$ and IL-1 and IL-6, IL-22 can be induced solely by IL-6 and preferentially by the activation of the transcription factor aryl hydrocarbon receptor (AHR) $[75,76]$.

As mentioned before, the pathological role of IL-22 has been demonstrated in several chronic inflammatory pathologies and mouse models of autoimmune diseases. In both cases the main focus has been the liver [77], the skin [78] and the gut [74]. Injection of IL-22 in mice causes the release of acute phase proteins including PAP1/Reg2 from the pancreas [79] and serum amyloid A from the liver [80]. In another study it was shown that hydrodynamic gene delivery of IL-22 cDNA in the liver significantly protected against injury, necrosis, and apoptosis induced by administration of ConA, carbon tetrachloride $\left(\mathrm{CCl}_{4}\right)$, or Fas agonist via the induction of several anti-apoptotic proteins, including Bcl-xL, Bcl-2, and Mcl-1 [81]. Consistent with this, IL-22 deficient mice have been shown to be highly sensitive to hepatitis [82].

A great deal of attention has been given to the role of IL-22 in the skin. Subcutaneous injection with recombinant IL-22 as well as IL-17A or TNF- $\alpha$ led to the upregulation of 
both CCL20 and CCR6 expression in skin as well as cutaneous T-cell infiltration [83]. IL-22 application in mice enhanced cutaneous S100A9 and MMP1 expression, two key proteins that are abundant in psoriatic skin $[84,85]$. Consistent with these observations, it has been reported that psoriatic patients showed strongly elevated plasma levels of IL-22 and that this correlates directly with the disease severity and indirectly with anti-psoriatic therapy [85].

Interesting results have also been obtained from the studies of the role of IL-22 in gut pathophysiology. Similar to the study on the liver, microinjection-based local genedelivery of IL-22 gene within colonic epithelial cells led to rapid amelioration of local intestinal inflammation in a mouse model of Th2-mediated colitis: the dextran sulfate sodium-induced colitis [86].

Many approaches have been used to further support these findings including the use of IL-22BP or neutralizing antibodies against IL-22. Overexpression of IL-22-binding protein suppressed goblet cell restitution during the recovery phase of a dextran sulfate sodium-induced model of acute colitis while administration of IL-22BP-Fc during septic peritonitis led to enhanced accumulation of neutrophils and mononuclear phagocytes and a reduced bacterial load at the site of infection [86]. Conversely, mice treated with IL-22neutralizing antibodies reduced acanthosis (thickening of the skin) and inflammatory infiltrates [78].

\section{Interleukin-23}

Interleukin-23, together with IL-27, is recently discovered cytokine structurally related to IL-12. In fact, while IL-12 is a heterodimeric cytokine composed of two disulfide-linked subunits, p35 and p40, IL-23 was identified after the isolation of p19 which is a novel partner of IL-12p40. Similarly to p35 subunit of IL-12, p19 requires coexpression of p40 for secretion. IL-23 is produced by activated monocytes and activated antigen-presenting cells (APC), including DCs and macrophages, T cells, B cells, and endothelial cells [87, $88]$. 

cell types such as microglia [91] and Paneth cells [92]. Initial studies on the biological functions of this cytokine proposed an overlapping action with IL-12 as inducer of IFN- $\gamma$ producing Th1 cells. However, IL-23 is now most known as a Th17 development promoting cytokine; it is important to note that IL-23 is not necessary for Th17 differentiation, but rather for expansion and maintenance of these effector cells [90, 93].

The link between IL-23 and Th17 cells has promoted a number of studies on the role of this cytokine in autoimmune inflammatory diseases. Here the initial attention focused on EAE and CIA, showing that IL-23-deficient mice are completely resistant to the development of this disease [94]. However, most of the recent studies on IL-23 evolve around its role in the development of intestinal inflammation where this cytokine seems to play a unique and critical role even when compared to other members of its family such as IL-12. Colonic DC seem to be the main cellular source of IL-23, and its production in the gut seems essential to overcome the suppressive effects of Treg cells, favouring the establishment of an immune response to intestinal pathogens [95]. Consistent with this hypothesis, IL-23 deficient mice have a marked increase in the number of FoxP3+ cells in the intestine [96].

More recent studies in humans have expanded the role of IL-23 as an intestinal-specific cytokine to sentinel of mucosal immunity. Infection of the gastric mucosa by the gramnegative bacterium Helicobacter pylori is considered one of the main causes of gastritis and ulcer; these conditions are mediated by the induction of IL-23 and the release of IL- 

homeostatic mucosal immunity. However, as with many other cytokines described here, IL-23 is a double-edged sword that, if produced in large non-physiological quantities, might also cause chronic inflammation. In fact, it has been shown that a population of CD14+ macrophages present in Crohn's disease patients produce high levels of IL-23 and that this in turn lead to the development of pathogenic IFN- $\gamma$ and IL-17 producing T cells [98]. Similar findings have been reported in spondylitis ankylosante where the increased production of IL-23 by Paneth cells appears to be the main cause of the intestinal inflammation characteristic of this disease [92]. Finally, and most importantly, a genomewide association study has shown that coding single-nucleotide polymorphism within the IL-23R, but not IL-12R $\beta 2$, predisposes and significantly correlates with susceptibility to inflammatory bowel disease $[99,100]$. As a consequence of the structural and functional similarities between IL-12 and IL-23, it seems probable that IL-23, like IL-12, would also have a function in the regulation of Th1-cell responses. These findings, together with the results of several clinical trials now under development, will further substantiate the suitability of IL-23 as promising target for the development of novel therapeutics for autoimmune chronic intestinal inflammation.

\section{Interleukin-27}

IL-27 belongs to the greater family of IL-6/IL-12 cytokine family and like its siblings IL12, IL-23 and IL-35, is a heterodimeric cytokine composed of Epstein-Barr virusinduced gene 3 (EBI-3), a p40-related molecule, and p28, a p35-related molecule. However, IL-27 differs from IL-12 and IL-23 in that its subunits are not tight together by a disulfide bond and this has led to the suggestions that p28 alone might be able to exert IL-27 biological effects [101]. In line with this hypothesis, the kinetic of p28 expression is significantly faster than that of EBI3 in activated DC. On the other hand, the scarce recovery of p28 in the extracellular medium of mouse and human cells does not provide support to this hypothesis [102]. 

bind IL-27 and IL-27ra-FC fusion protein has been shown to neutralize IL-27, the presence of gp130 is essential for signal transduction. Leukocytes of both adaptive and innate immune arms such as neutrophils, monocytes, mast cells, T, B and NK cells express IL-27R while IL-27 has been shown to be mainly produced by APC during inflammatory conditions. The signalling pathway initiated by IL-27 activates JAK1 and JAK2, resulting in phosphorylation of STAT1, STAT2, STAT3, and STAT5 in naive CD4+ T cells. However, only STAT1 and STAT3 are critical to IL-27 bioactivity, as demonstrated by the loss of IL-27 activity in STAT1- and STAT3-deficient mice [102$104]$.

Among all the cytokines described here, IL-27 is the most well known for its "dual personality". Indeed, several lines of evidence initially proposed that IL-27 is a proinflammatory cytokine that promotes Th1 differentiation thanks to its ability to induce the release of IFN- $\gamma$ by unpolarized $\mathrm{T}$ cells and because of the reduced production of IFN- $\gamma$ by antigen-stimulated IL-27ra-deficient cells. Most interestingly, when compared to its mother cytokine IL-12, IL-27 is released by APC soon after their activation and IL$27 \mathrm{R}$ is expressed by naïve $\mathrm{T}$ cells while $\mathrm{IL}-12 \mathrm{R} \beta 2$ is absent in these cells $[105,106]$. Together these findings point to IL-27 as key cytokine governing the initial phase of naïve T cells differentiation in Th1 effector cells.

However, this scenario changed significantly after the generation of IL-27ra knock out mice since it was found that these animals had only a transient defect in Th1 polarization following infection with Leishmania major and normal IFN- $\gamma$ production at the later stage of the disease when the parasite starts to proliferate [107]. Most strikingly, using other mouse models of infections Tripanosoma cruzi [108] or Tripanosoma gondii [109] it was noted that IL-27ra-deficient mice developed severe organ damages as a result of exacerbated activation of T cells. Similar findings have been described for a number of other cell types where while the cytokine per se induced the activation of these cells in vitro, the analysis of the IL-27ra-deficient mice gave opposite results. For instance, 
Other studies further consolidated the antinflammatory property of IL-27. The mechanisms underlying this effect are not clear as yet but include the suppression of several key inflammatory cytokines such as IL-2, IL-6 and IL-17. In CD4 T cells, IL-27 inhibits the differentiation of Th17 cells while in CD8 T cell it enhances cytotoxic activity against tumours. IL-27 also influences B-cell differentiation and immunoglobulin production inducing proliferation of activated naive but not memory B cells [103]. Recombinant IL-27 suppresses reactive oxygen intermediates production by activated macrophages and neutrophils [112] and DCs from IL-27ra deficient mice showed an increased response to LPS stimulation by expression of CD80 and CD86 costimulatory molecules and Th1-related cytokine genes [103].

\section{Interleukin-33}

Of all the cytokines that are described in this review, IL-33 is the most recently discovered. IL-33 was first described in 2005 and belongs to the IL-1 cytokine family [113]. Like IL-1 and IL-18, IL-33 is expressed as prodomains and only become functionally mature proteins following proteolytic processing by caspase-1. In fact, in vitro incubation of IL-33 with caspase-1 yielded an $18 \mathrm{kDa}$ mature protein from a $30 \mathrm{kDa}$ precursor $[114,115]$. Interestingly, the pro-form of IL-33 has been found to localize in the nucleus thanks to a nuclear localization sequence present in the propeptide and proposed to function as transcriptional repressor [116]. However, the exact role of nuclear pro-IL-33 is still not known.

The receptor for IL-33 is a heterodimer composed of ST2, the orphan IL-1 family receptor, and IL-1RAcP, and it is present in a transmembrane and secreted form. The transmembrane form is expressed primarily on mast cells and Th2 cells and thus thought to play a key role in the development of a Th2 response [117]. Consistent with this, administration of recombinant IL-33 both in vitro and in vivo causes the release of Th2 
cytokines IL-5 and IL-13 while suppressing the production of Th1 cytokine IFN- $\gamma$ [118]. The soluble isoform originates from differential mRNA processing and because of this lack of nine amino acids present at the $\mathrm{C}$-terminus of the molecule. This spliced isoform is produced by antigen presenting cells such as monocytes and macrophages and acts as decoy receptor and thus antagonizes the effects of IL-33 [119, 120]. In fact, patients suffering chronic inflammatory diseases have high levels of soluble ST2 [121, 122].

IL-33 is widely expressed in several tissues and cell types including smooth muscle cells, epithelial cells, fibroblasts, keratynocytes, dendritic cells and activated macrophages. Binding of IL-33 to ST2 homodimers activates a cascade of signalling events leading to the activation of NF-kB and several MAPKs. Other studies have also shown that IL-33 can activate a heterodimeric receptor complex composed by ST2 and IL-1RAcP and thus initiate the classical IL-1 signalling cascade involving Erk, p38 and JNK activation [115].

Administration of IL-33 in the peritoneal cavity of mice induced a selective increase of mononuclear cells, eosinophils and plasma cells in the spleen while in the lung led to the accumulation of eosinophils and mononuclear cells [123]. These effects are consistent with its ability to induce a Th2 response and to act as chemoattractant for Th2 cells [118]. In addition, IL-33 has been shown to promote the differentiation of CD34+ precursor cells in mast cells [124] and to induce the release of several inflammatory cytokines such as TNF- $\alpha$, IL-1 $\beta$, IL-6 and MCP-1 from bone marrow derived mast cells [125]. These findings are particularly interesting since recent views on the pathogenesis of RA suggest that activation of mast cells might play an important role in the pathogenesis of this disease. In this context, there seems it is possible to envisage a link between IL-33, mast cells and RA [126]. Administration of soluble ST2 has been proved to decrease the development of this disease possibly via direct inhibition of macrophage activation [127]. Further studies using similar pharmacological tools have been carried out in mouse models of septic shock where administration of soluble ST2 was found to reduce systemic inflammation and mortality [128].

\section{Conclusions}



revolutionized the field and changed the way we look now at both the early and late stage of inflammation. In fact we now know that there are a number of "early inflammatory cytokines" such as IL-1, IL-8 and TNF- $\alpha$, just to name a few, that play a key role to the initiation of the inflammatory response like prostaglandins and kinines. In addition to this, the scientific community has also filled in the "empty box" of the signalling pathways governing chronic inflammation and provided us with a long list of cytokines that appear to be promising targets for the treatment of a variety of chronic autoimmune diseases. We have provided here a brief description of few selected recent ones that are emerging as the next "holy grail" to treat inflammation and summarized their main structural and biological features (Table I and II).

However, we cannot help notice that there is still a great deal of "segregation" within the scientific community that leads them to sectorialize themselves in specific niches and loose track of the "bigger picture". Indeed, it is now becoming clear that there is not a 
In this respect, we think that more fruitful discoveries will be available when scientists will loosen up their boundaries and approach the study of novel mediators of inflammation with a more open mind i.e. without putting their bets on $\underline{\mathbf{a}}$ given molecule in $\underline{\mathbf{a}}$ specific cell in the context of $\underline{\mathbf{a}}$ specific inflammatory disease. Similar efforts might revealed useful when, in a opposite way, we do not recognize individuality to different inflammatory pathologies and thus we think that a novel treatment for rheumatoid arthritis will be also effective in multiple sclerosis, psoriasis or systemic lupus erythematosus.

Thus, the discovery of a novel mediator of inflammation should prompt scientist, and especially biochemical pharmacologists, to first explore the effects of this novel mediators in "far-distant" cellular and physio/pathological contexts and second to investigate how tissue and disease specific these effects are. In a similar fashion, researchers interested in the discovery of new antinflammatory drugs or natural bioactive compounds should not limit their investigations only to the well-known mediators of inflammation but also to these fashionable and recently discovered molecules. This openarm approach might significantly accelerate the discovery of novel effective therapeutic strategies and avoid a "rush to judgement" [29] we have seen so far applied to inflammation and immune biology research.

We think that the history and curriculum vitae of Aspirin provide us with a very good example of expanding initial findings and incorporating novel information that can significantly change the way we use a drug in the clinic. Indeed, after the initial discovery of Aspirin as cyclooxygenase inhibitor, we now know that aspirin and salicylic acid act also as inhibitors of NF- $\kappa \mathrm{B}$ activation when given at high doses [129] or that can trigger 
the transcellular biosynthesis of a series of 15-epimer (aspirin-triggered 15-epi-LXA $\left.\mathrm{L}_{4}\right)$ [130], which share many anti-inflammatory activities with the native $\mathrm{LXA}_{4}$.

We think that this continuously evolving story on the molecular mechanisms responsible for the anti-inflammatory effects of Aspirin is the main reason behind the long lasting success of this drug. In light of this consideration, we hope that in the future researchers will consider the discovery of mediators of inflammation not only as novel "piece of biology" but also the starting point to ask themselves one simple and important question: are we going to change the box with Aspirin in our cupboard at home with something safer?

\section{Acknowledgments}

We would like to thank Dr. Dianne Cooper, Prof. Mauro Perretti and Prof. Rod Flower for helpful suggestions and careful reading of the manuscript. FM and MPR are supported by the British Hearth Foundation (project grant number PG/06/153/22042). 
References

[1] Medzhitov R. Origin and physiological roles of inflammation. Nature 2008;454:428-35.

[2] Serhan CN, Brain SD, Buckley CD, Gilroy DW, Haslett C, O'Neill LA, et al. Resolution of inflammation: state of the art, definitions and terms. Faseb $\mathrm{J}$ 2007;21:325-32.

[3] Serhan CN, Chiang N, Van Dyke TE. Resolving inflammation: dual antiinflammatory and pro-resolution lipid mediators. Nat Rev Immunol 2008;8:34961.

[4] Atassi MZ, Casali P. Molecular mechanisms of autoimmunity. Autoimmunity 2008;41:123-32.

[5] Kanegane H, Tosato G. Activation of naive and memory $\mathrm{T}$ cells by interleukin15. Blood 1996;88:230-5.

[6] Rochman Y, Spolski R, Leonard WJ. New insights into the regulation of T cells by gamma(c) family cytokines. Nat Rev Immunol 2009;9:480-90.

[7] Orinska Z, Maurer M, Mirghomizadeh F, Bulanova E, Metz M, Nashkevich N, et al. IL-15 constrains mast cell-dependent antibacterial defenses by suppressing chymase activities. Nat Med 2007;13:927-34.

[8] Tagaya Y, Bamford RN, DeFilippis AP, Waldmann TA. IL-15: a pleiotropic cytokine with diverse receptor/signaling pathways whose expression is controlled at multiple levels. Immunity 1996;4:329-36.

[9] Tagaya Y, Kurys G, Thies TA, Losi JM, Azimi N, Hanover JA, et al. Generation of secretable and nonsecretable interleukin 15 isoforms through alternate usage of signal peptides. Proc Natl Acad Sci U S A 1997;94:14444-9.

[10] He YW, Malek TR. The structure and function of gamma c-dependent cytokines and receptors: regulation of $\mathrm{T}$ lymphocyte development and homeostasis. Crit Rev Immunol 1998;18:503-24.

[11] Onu A, Pohl T, Krause H, Bulfone-Paus S. Regulation of IL-15 secretion via the leader peptide of two IL-15 isoforms. J Immunol 1997;158:255-62.

[12] Sato N, Patel HJ, Waldmann TA, Tagaya Y. The IL-15/IL-15Ralpha on cell surfaces enables sustained IL-15 activity and contributes to the long survival of CD8 memory T cells. Proc Natl Acad Sci U S A 2007;104:588-93.

[13] Suzuki H, Duncan GS, Takimoto H, Mak TW. Abnormal development of intestinal intraepithelial lymphocytes and peripheral natural killer cells in mice lacking the IL-2 receptor beta chain. J Exp Med 1997;185:499-505.

[14] Schluns KS, Nowak EC, Cabrera-Hernandez A, Puddington L, Lefrancois L, Aguila HL. Distinct cell types control lymphoid subset development by means of IL-15 and IL-15 receptor alpha expression. Proc Natl Acad Sci U S A 2004; 101:5616-21.

[15] Wilkinson PC, Liew FY. Chemoattraction of human blood T lymphocytes by interleukin-15. J Exp Med 1995;181:1255-9. 
[29] Steinman L. A rush to judgment on Th17. J Exp Med 2008;205:1517-22.

[30] Fantuzzi G, Dinarello CA. Interleukin-18 and interleukin-1 beta: two cytokine substrates for ICE (caspase-1). J Clin Immunol 1999;19:1-11.

[31] Novick D, Rubinstein M. The tale of soluble receptors and binding proteins: from bench to bedside. Cytokine Growth Factor Rev 2007;18:525-33.

[32] Novick D, Kim SH, Fantuzzi G, Reznikov LL, Dinarello CA, Rubinstein M. Interleukin-18 binding protein: a novel modulator of the Th1 cytokine response. Immunity 1999;10:127-36.

[33] Fantuzzi G, Banda NK, Guthridge C, Vondracek A, Kim SH, Siegmund B, et al. Generation and characterization of mice transgenic for human IL-18-binding protein isoform a. J Leukoc Biol 2003;74:889-96.

[34] Dunne A, O'Neill LA. The interleukin-1 receptor/Toll-like receptor superfamily: signal transduction during inflammation and host defense. Sci STKE 2003;2003:re3.

[16] Badolato R, Ponzi AN, Millesimo M, Notarangelo LD, Musso T. Interleukin-15 (IL-15) induces IL-8 and monocyte chemotactic protein 1 production in human monocytes. Blood 1997;90:2804-9.

[17] Fehniger TA, Caligiuri MA. Interleukin 15: biology and relevance to human disease. Blood 2001;97:14-32.

[18] McInnes IB, Liew FY. Interleukin 15: a proinflammatory role in rheumatoid arthritis synovitis. Immunol Today 1998;19:75-9.

[19] Dong C. TH17 cells in development: an updated view of their molecular identity and genetic programming. Nat Rev Immunol 2008;8:337-48.

[20] Oukka M. Th17 cells in immunity and autoimmunity. Ann Rheum Dis 2008;67 Suppl 3:iii26-9.

[21] Kolls JK, Linden A. Interleukin-17 family members and inflammation. Immunity 2004;21:467-76.

[22] Gaffen SL. An overview of IL-17 function and signaling. Cytokine 2008;43:402-

[23] Rong Z, Wang A, Li Z, Ren Y, Cheng L, Li Y, et al. IL-17RD (Sef or IL-17RLM) interacts with IL-17 receptor and mediates IL-17 signaling. Cell Res 2009;19:20815. immune responses and host defense against pathogens. Immunol Rev 2008;226:57-79. stimulates granulopoiesis in mice: use of an alternate, novel gene therapy-derived method for in vivo evaluation of cytokines. J Immunol 1998;161:6383-9. Interleukin 17 sustains rather than induces inflammation. Biochem Pharmacol 2009;77:878-87.

[27] Awasthi A, Kuchroo VK. Th17 cells: from precursors to players in inflammation and infection. Int Immunol 2009;21:489-98.

[28] Fouser LA, Wright JF, Dunussi-Joannopoulos K, Collins M. Th17 cytokines and their emerging roles in inflammation and autoimmunity. Immunol Rev $2008 \cdot 226 \cdot 87-102$ 
[46] Hoshino T, Kawase Y, Okamoto M, Yokota K, Yoshino K, Yamamura K, et al. Cutting edge: IL-18-transgenic mice: in vivo evidence of a broad role for IL-18 in modulating immune function. J Immunol 2001;166:7014-8.

[47] Dinarello CA. Interleukin-18 and the pathogenesis of inflammatory diseases. Semin Nephrol 2007;27:98-114.

[48] Smeets RL, van de Loo FA, Arntz OJ, Bennink MB, Joosten LA, van den Berg WB. Adenoviral delivery of IL-18 binding protein C ameliorates collageninduced arthritis in mice. Gene Ther 2003;10:1004-11.

[49] Banda NK, Vondracek A, Kraus D, Dinarello CA, Kim SH, Bendele A, et al. Mechanisms of inhibition of collagen-induced arthritis by murine IL-18 binding protein. J Immunol 2003;170:2100-5. 
[50] Parrish-Novak J, Dillon SR, Nelson A, Hammond A, Sprecher C, Gross JA, et al. Interleukin 21 and its receptor are involved in NK cell expansion and regulation of lymphocyte function. Nature 2000;408:57-63.

[51] Leonard WJ, Spolski R. Interleukin-21: a modulator of lymphoid proliferation, apoptosis and differentiation. Nat Rev Immunol 2005;5:688-98.

[52] Mehta DS, Wurster AL, Grusby MJ. Biology of IL-21 and the IL-21 receptor. Immunol Rev 2004;202:84-95.

[53] Collins M, Whitters MJ, Young DA. IL-21 and IL-21 receptor: a new cytokine pathway modulates innate and adaptive immunity. Immunol Res 2003;28:131-40.

[54] Pesce J, Kaviratne M, Ramalingam TR, Thompson RW, Urban JF, Jr., Cheever AW, et al. The IL-21 receptor augments Th2 effector function and alternative macrophage activation. J Clin Invest 2006;116:2044-55.

[55] Fina D, Sarra M, Fantini MC, Rizzo A, Caruso R, Caprioli F, et al. Regulation of gut inflammation and th17 cell response by interleukin-21. Gastroenterology 2008; 134:1038-48.

[56] Wei L, Laurence A, Elias KM, O'Shea JJ. IL-21 is produced by Th17 cells and drives IL-17 production in a STAT3-dependent manner. J Biol Chem 2007;282:34605-10.

[57] Ozaki K, Spolski R, Ettinger R, Kim HP, Wang G, Qi CF, et al. Regulation of B cell differentiation and plasma cell generation by IL-21, a novel inducer of Blimp1 and Bcl-6. J Immunol 2004;173:5361-71.

[58] Konforte D, Simard N, Paige CJ. IL-21: an executor of B cell fate. J Immunol 2009;182:1781-7.

[59] Ettinger R, Kuchen S, Lipsky PE. The role of IL-21 in regulating B-cell function in health and disease. Immunol Rev 2008;223:60-86.

[60] Brandt K, Bulfone-Paus S, Foster DC, Ruckert R. Interleukin-21 inhibits dendritic cell activation and maturation. Blood 2003;102:4090-8.

[61] Fantini MC, Rizzo A, Fina D, Caruso R, Becker C, Neurath MF, et al. IL-21 regulates experimental colitis by modulating the balance between Treg and Th17 cells. Eur J Immunol 2007;37:3155-63.

[62] Zeng R, Spolski R, Finkelstein SE, Oh S, Kovanen PE, Hinrichs CS, et al. Synergy of IL-21 and IL-15 in regulating CD8+ T cell expansion and function. J Exp Med 2005;201:139-48.

[63] White L, Krishnan S, Strbo N, Liu H, Kolber MA, Lichtenheld MG, et al. Differential effects of IL-21 and IL-15 on perforin expression, lysosomal degranulation, and proliferation in CD8 $\mathrm{T}$ cells of patients with human immunodeficiency virus-1 (HIV). Blood 2007;109:3873-80.

[64] Sivori S, Cantoni C, Parolini S, Marcenaro E, Conte R, Moretta L, et al. IL-21 induces both rapid maturation of human CD34+ cell precursors towards NK cells and acquisition of surface killer Ig-like receptors. Eur J Immunol 2003;33:343947.

[65] Kasaian MT, Whitters MJ, Carter LL, Lowe LD, Jussif JM, Deng B, et al. IL-21 limits NK cell responses and promotes antigen-specific $\mathrm{T}$ cell activation: a mediator of the transition from innate to adaptive immunity. Immunity 2002; 16:559-69. 
[66] Herber D, Brown TP, Liang S, Young DA, Collins M, Dunussi-Joannopoulos K. IL-21 has a pathogenic role in a lupus-prone mouse model and its blockade with IL-21R.Fc reduces disease progression. J Immunol 2007;178:3822-30.

[67] Jang E, Cho SH, Park H, Paik DJ, Kim JM, Youn J. A positive feedback loop of IL-21 signaling provoked by homeostatic CD4+CD25- $\mathrm{T}$ cell expansion is essential for the development of arthritis in autoimmune $\mathrm{K} / \mathrm{BxN}$ mice. J Immunol 2009; 182:4649-56.

[68] Young DA, Hegen M, Ma HL, Whitters MJ, Albert LM, Lowe L, et al. Blockade of the interleukin-21/interleukin-21 receptor pathway ameliorates disease in animal models of rheumatoid arthritis. Arthritis Rheum 2007;56:1152-63.

[69] Vollmer TL, Liu R, Price M, Rhodes S, La Cava A, Shi FD. Differential effects of IL-21 during initiation and progression of autoimmunity against neuroantigen. J Immunol 2005;174:2696-701.

[70] Nagem RA, Ferreira Junior JR, Dumoutier L, Renauld JC, Polikarpov I. Interleukin-22 and its crystal structure. Vitam Horm 2006;74:77-103.

[71] Wolk K, Sabat R. Interleukin-22: a novel T- and NK-cell derived cytokine that regulates the biology of tissue cells. Cytokine Growth Factor Rev 2006;17:36780 .

[72] Zenewicz LA, Flavell RA. IL-22 and inflammation: leukin' through a glass onion. Eur J Immunol 2008;38:3265-8.

[73] Pestka S, Krause CD, Sarkar D, Walter MR, Shi Y, Fisher PB. Interleukin-10 and related cytokines and receptors. Annu Rev Immunol 2004;22:929-79.

[74] Aujla SJ, Kolls JK. IL-22: a critical mediator in mucosal host defense. J Mol Med 2009;87:451-4.

[75] Takatori H, Kanno Y, Watford WT, Tato CM, Weiss G, Ivanov, II, et al. Lymphoid tissue inducer-like cells are an innate source of IL-17 and IL-22. J Exp Med 2009;206:35-41.

[76] Veldhoen M, Hirota K, Westendorf AM, Buer J, Dumoutier L, Renauld JC, et al. The aryl hydrocarbon receptor links TH17-cell-mediated autoimmunity to environmental toxins. Nature 2008;453:106-9.

[77] Radaeva S, Sun R, Pan HN, Hong F, Gao B. Interleukin 22 (IL-22) plays a protective role in T cell-mediated murine hepatitis: IL-22 is a survival factor for hepatocytes via STAT3 activation. Hepatology 2004;39:1332-42.

[78] Ma HL, Liang S, Li J, Napierata L, Brown T, Benoit S, et al. IL-22 is required for Th17 cell-mediated pathology in a mouse model of psoriasis-like skin inflammation. J Clin Invest 2008;118:597-607.

[79] Aggarwal S, Xie MH, Maruoka M, Foster J, Gurney AL. Acinar cells of the pancreas are a target of interleukin-22. J Interferon Cytokine Res 2001;21:104753.

[80] Nagalakshmi ML, Rascle A, Zurawski S, Menon S, de Waal Malefyt R. Interleukin-22 activates STAT3 and induces IL-10 by colon epithelial cells. Int Immunopharmacol 2004;4:679-91.

[81] Pan H, Hong F, Radaeva S, Gao B. Hydrodynamic gene delivery of interleukin-22 protects the mouse liver from concanavalin A-, carbon tetrachloride-, and Fas ligand-induced injury via activation of STAT3. Cell Mol Immunol 2004;1:43-9. 
[82] Zenewicz LA, Yancopoulos GD, Valenzuela DM, Murphy AJ, Karow M, Flavell RA. Interleukin-22 but not interleukin-17 provides protection to hepatocytes during acute liver inflammation. Immunity 2007;27:647-59.

[83] Harper EG, Guo C, Rizzo H, Lillis JV, Kurtz SE, Skorcheva I, et al. Th17 Cytokines Stimulate CCL20 Expression in Keratinocytes In Vitro and In Vivo: Implications for Psoriasis Pathogenesis. J Invest Dermatol 2009.

[84] Liang SC, Tan XY, Luxenberg DP, Karim R, Dunussi-Joannopoulos K, Collins $\mathrm{M}$, et al. Interleukin (IL)-22 and IL-17 are coexpressed by Th17 cells and cooperatively enhance expression of antimicrobial peptides. $\mathrm{J}$ Exp Med 2006;203:2271-9.

[85] Wolk K, Witte E, Wallace E, Docke WD, Kunz S, Asadullah K, et al. IL-22 regulates the expression of genes responsible for antimicrobial defense, cellular differentiation, and mobility in keratinocytes: a potential role in psoriasis. Eur $\mathbf{J}$ Immunol 2006;36:1309-23.

[86] Sugimoto K, Ogawa A, Mizoguchi E, Shimomura Y, Andoh A, Bhan AK, et al. IL-22 ameliorates intestinal inflammation in a mouse model of ulcerative colitis. J Clin Invest 2008;118:534-44.

[87] Lankford CS, Frucht DM. A unique role for IL-23 in promoting cellular immunity. J Leukoc Biol 2003;73:49-56.

[88] Frucht DM. IL-23: a cytokine that acts on memory $T$ cells. Sci STKE 2002;2002:PE1.

[89] Watford WT, Hissong BD, Bream JH, Kanno Y, Muul L, O'Shea JJ. Signaling by IL-12 and IL-23 and the immunoregulatory roles of STAT4. Immunol Rev 2004;202:139-56.

[90] Tato CM, Cua DJ. Reconciling id, ego, and superego within interleukin-23. Immunol Rev 2008;226:103-11.

[91] Becher B, Durell BG, Noelle RJ. IL-23 produced by CNS-resident cells controls $\mathrm{T}$ cell encephalitogenicity during the effector phase of experimental autoimmune encephalomyelitis. J Clin Invest 2003;112:1186-91.

[92] Ciccia F, Bombardieri M, Principato A, Giardina A, Tripodo C, Porcasi R, et al. Overexpression of interleukin-23, but not interleukin-17, as an immunologic signature of subclinical intestinal inflammation in ankylosing spondylitis. Arthritis Rheum 2009;60:955-65.

[93] Boniface K, Blom B, Liu YJ, de Waal Malefyt R. From interleukin-23 to T-helper 17 cells: human T-helper cell differentiation revisited. Immunol Rev 2008;226:132-46.

[94] Furuzawa-Carballeda J, Vargas-Rojas MI, Cabral AR. Autoimmune inflammation from the Th17 perspective. Autoimmun Rev 2007;6:169-75.

[95] Leithauser F, Meinhardt-Krajina T, Fink K, Wotschke B, Moller P, Reimann J. Foxp3-expressing CD103+ regulatory $\mathrm{T}$ cells accumulate in dendritic cell aggregates of the colonic mucosa in murine transfer colitis. Am J Pathol 2006;168:1898-909.

[96] Izcue A, Hue S, Buonocore S, Arancibia-Carcamo CV, Ahern PP, Iwakura Y, et al. Interleukin-23 restrains regulatory $\mathrm{T}$ cell activity to drive $\mathrm{T}$ cell-dependent colitis. Immunity 2008;28:559-70. 
[106] Villarino AV, Larkin J, 3rd, Saris CJ, Caton AJ, Lucas S, Wong T, et al. Positive and negative regulation of the IL-27 receptor during lymphoid cell activation. $\mathrm{J}$ Immunol 2005;174:7684-91.

[107] Yoshida H, Hamano S, Senaldi G, Covey T, Faggioni R, Mu S, et al. WSX-1 is required for the initiation of Th1 responses and resistance to L. major infection. Immunity 2001;15:569-78.

[108] Hamano S, Himeno K, Miyazaki Y, Ishii K, Yamanaka A, Takeda A, et al. WSX1 is required for resistance to Trypanosoma cruzi infection by regulation of proinflammatory cytokine production. Immunity 2003;19:657-67.

[109] Villarino A, Hibbert L, Lieberman L, Wilson E, Mak T, Yoshida H, et al. The IL27R (WSX-1) is required to suppress $\mathrm{T}$ cell hyperactivity during infection. Immunity 2003;19:645-55.

[110] Larousserie F, Pflanz S, Coulomb-L'Hermine A, Brousse N, Kastelein R, Devergne O. Expression of IL-27 in human Th1-associated granulomatous diseases. J Pathol 2004;202:164-71.

[111] Artis D, Villarino A, Silverman M, He W, Thornton EM, Mu S, et al. The IL-27 receptor (WSX-1) is an inhibitor of innate and adaptive elements of type 2 immunity. J Immunol 2004; 173:5626-34.

[112] Wirtz S, Tubbe I, Galle PR, Schild HJ, Birkenbach M, Blumberg RS, et al. Protection from lethal septic peritonitis by neutralizing the biological function of interleukin 27. J Exp Med 2006;203:1875-81.

[97] Caruso R, Pallone F, Monteleone G. Emerging role of IL-23/IL-17 axis in H pylori-associated pathology. World J Gastroenterol 2007;13:5547-51.

[98] Caruso R, Sarra M, Stolfi C, Rizzo A, Fina D, Fantini MC, et al. Interleukin-25 inhibits interleukin-12 production and Th1 cell-driven inflammation in the gut. Gastroenterology 2009;136:2270-9.

[99] Amre DK, Mack D, Israel D, Morgan K, Lambrette P, Law L, et al. Association between genetic variants in the IL-23R gene and early-onset Crohn's disease: results from a case-control and family-based study among Canadian children. Am receptor (IL-23R) gene protects against pediatric Crohn's disease. Inflamm Bowel Dis 2007;13:511-5.

[102] Batten M, Ghilardi N. The biology and therapeutic potential of interleukin 27. J Mol Med 2007;85:661-72.

[103] Yoshida H, Yoshiyuki M. Regulation of immune responses by interleukin-27. Immunol Rev 2008;226:234-47.

[104] Kastelein RA, Hunter CA, Cua DJ. Discovery and biology of IL-23 and IL-27: related but functionally distinct regulators of inflammation. Annu Rev Immunol 2007;25:221-42.

[105] Pflanz S, Timans JC, Cheung J, Rosales R, Kanzler H, Gilbert J, et al. IL-27, a heterodimeric cytokine composed of EBI3 and p28 protein, induces proliferation of naive CD4(+) T cells. Immunity 2002;16:779-90. 
[113] Dinarello CA. An IL-1 family member requires caspase-1 processing and signals through the ST2 receptor. Immunity 2005;23:461-2.

[114] Arend WP, Palmer G, Gabay C. IL-1, IL-18, and IL-33 families of cytokines. Immunol Rev 2008;223:20-38.

[115] Gadina M, Jefferies CA. IL-33: a sheep in wolf's clothing? Sci STKE 2007;2007:pe31.

[116] Carriere V, Roussel L, Ortega N, Lacorre DA, Americh L, Aguilar L, et al. IL-33, the IL-1-like cytokine ligand for ST2 receptor, is a chromatin-associated nuclear factor in vivo. Proc Natl Acad Sci U S A 2007;104:282-7.

[117] Kakkar R, Lee RT. The IL-33/ST2 pathway: therapeutic target and novel biomarker. Nat Rev Drug Discov 2008;7:827-40.

[118] Komai-Koma M, Xu D, Li Y, McKenzie AN, McInnes IB, Liew FY. IL-33 is a chemoattractant for human Th2 cells. Eur J Immunol 2007;37:2779-86.

[119] Iwahana H, Yanagisawa K, Ito-Kosaka A, Kuroiwa K, Tago K, Komatsu N, et al. Different promoter usage and multiple transcription initiation sites of the interleukin-1 receptor-related human ST2 gene in UT-7 and TM12 cells. Eur J Biochem 1999;264:397-406.

[120] Tominaga S, Kuroiwa K, Tago K, Iwahana H, Yanagisawa K, Komatsu N. Presence and expression of a novel variant form of ST2 gene product in human leukemic cell line UT-7/GM. Biochem Biophys Res Commun 1999;264:14-8.

[121] Bruneau S, Le Berre L, Herve C, Valanciute A, Kamal M, Naulet J, et al. Potential Role of Soluble ST2 Protein in Idiopathic Nephrotic Syndrome Recurrence Following Kidney Transplantation. Am J Kidney Dis 2009.

[122] Mueller T, Dieplinger B, Gegenhuber A, Poelz W, Pacher R, Haltmayer M. Increased plasma concentrations of soluble ST2 are predictive for 1-year mortality in patients with acute destabilized heart failure. Clin Chem 2008;54:752-6.

[123] Schmitz J, Owyang A, Oldham E, Song Y, Murphy E, McClanahan TK, et al. IL33, an interleukin-1-like cytokine that signals via the IL-1 receptor-related protein ST2 and induces T helper type 2-associated cytokines. Immunity 2005;23:479-90.

[124] Allakhverdi Z, Smith DE, Comeau MR, Delespesse G. Cutting edge: The ST2 ligand IL-33 potently activates and drives maturation of human mast cells. J Immunol 2007;179:2051-4.

[125] Moulin D, Donze O, Talabot-Ayer D, Mezin F, Palmer G, Gabay C. Interleukin (IL)-33 induces the release of pro-inflammatory mediators by mast cells. Cytokine 2007;40:216-25.

[126] Xu D, Jiang HR, Kewin P, Li Y, Mu R, Fraser AR, et al. IL-33 exacerbates antigen-induced arthritis by activating mast cells. Proc Natl Acad Sci U S A 2008;105:10913-8.

[127] Leung BP, Xu D, Culshaw S, McInnes IB, Liew FY. A novel therapy of murine collagen-induced arthritis with soluble T1/ST2. J Immunol 2004;173:145-50.

[128] Sweet MJ, Leung BP, Kang D, Sogaard M, Schulz K, Trajkovic V, et al. A novel pathway regulating lipopolysaccharide-induced shock by ST2/T1 via inhibition of Toll-like receptor 4 expression. J Immunol 2001;166:6633-9.

[129] Kopp E, Ghosh S. Inhibition of NF-kappa B by sodium salicylate and aspirin. Science 1994;265:956-9. 
[130] Claria J, Serhan CN. Aspirin triggers previously undescribed bioactive eicosanoids by human endothelial cell-leukocyte interactions. Proc Natl Acad Sci U S A 1995;92:9475-9. 
Figure legend.

Figure 1. Scientific "dilemma" faced by biochemical pharmacologists whishing to find "the right switch" to shut down inflammation. 


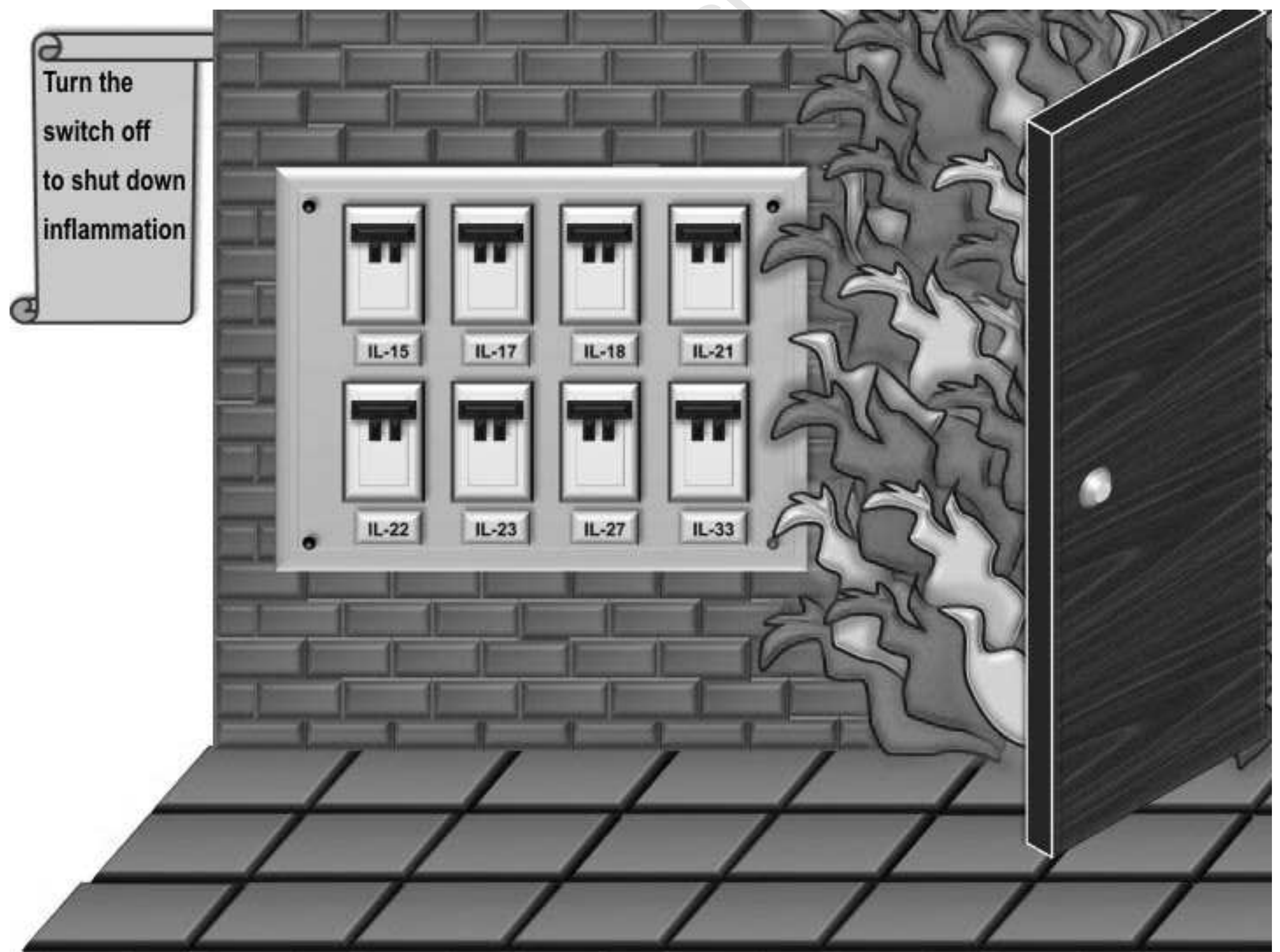




\begin{tabular}{|c|c|c|c|c|}
\hline Designation & $\begin{array}{l}\text { Cytokine } \\
\text { family }\end{array}$ & Structural features & $\begin{array}{l}\text { Cellular/tissue } \\
\text { distribution }\end{array}$ & Biological functions \\
\hline IL-15 & IL-2 & Four helical bundle cytokine & $\begin{array}{c}\text { Monocytes, macrophages, } \\
\text { dendritic cells, T cells and } \\
\text { mast cells }\end{array}$ & $\begin{array}{l}\text {-CD4 and CD8 T cell proliferation } \\
\text {-Chemoattractant for T cell and neutrophils } \\
\text {-Development of NK cells and intestinal intraepithelial lymphocytes }\end{array}$ \\
\hline IL-17A to $\mathrm{F}$ & IL-17 & $\begin{array}{l}\text { Homo/Heterodimer; structural } \\
\text { homolog of the cysteine knot } \\
\text { family }\end{array}$ & $\begin{array}{l}\text { Th17 cells, neutrophils, } \\
\text { epithelial and endothelial cells }\end{array}$ & $\begin{array}{l}\text {-Production of chemokines (IL-8, MCP-1, Gro- } \alpha \text { ), cytokines (G-CSF, (GM)-CSF, } \\
\text { IL-1, IL-6, TNF- } \alpha \text { ) and PGE }{ }_{2} \\
\text {-PMN recruitment } \\
\text {-Granulopoiesis and development of autoimmune disease }\end{array}$ \\
\hline IL-18 & $\mathrm{IL}-1$ & $\begin{array}{l}\text { Pro-form: } 22 \mathrm{kDa} \\
\text { Mature form: } 18 \mathrm{kDa}\end{array}$ & $\begin{array}{l}\text { Activated monocytes and } \\
\text { macrophages }\end{array}$ & $\begin{array}{l}\text {-Clearance of intracellular pathogens and viruses } \\
-\mathrm{IL}-13 \text { production by T and NK cells }\end{array}$ \\
\hline IL-21 & IL-2 & $\begin{array}{l}\text { Pro-form: } 162 \text { amino acids, } \\
\text { Mature form: } 131 \text { amino acids, } \\
15 \mathrm{kDa}\end{array}$ & Activated CD4 T cells & $\begin{array}{l}\text {-Proliferation and survival of B cells } \\
\text {-Inhibition of DC differentiation } \\
\text {-Inhibition of Treg development } \\
\text {-CD8 T cell antitumor functions } \\
\text {-Differentiation of CD4 cells in Th17 } \\
\text {-NK cell maturation and apoptosis }\end{array}$ \\
\hline IL-22 & $\mathrm{IL}-10$ & $\begin{array}{l}\text { Homo/Heterodimer } \\
\text { helix bundle }\end{array}$ & $\begin{array}{l}\text { Th1, Th17, NK T cells, } \gamma \delta \mathrm{T} \\
\text { cells, mast cells and CD11c } \\
\text { cells. }\end{array}$ & $\begin{array}{l}\text {-Release of acute phase proteins } \\
\text {-Expression of CCL20, CCR6 and MMP1 in the skin }\end{array}$ \\
\hline IL-23 & IL-12 & $\begin{array}{l}\text { Heterodimer composed by two } \\
\text { subunits ( } p 19 \text { and } p 40)\end{array}$ & $\begin{array}{l}\text { Monocytes, activated antigen } \\
\text { presenting cells, T cells, B } \\
\text { cells, endothelial cells, } \\
\text { microglia and Paneth cells }\end{array}$ & $\begin{array}{l}\text {-IFN-y producing Th1 cells } \\
\text {-Differentiation of CD4 cells in Th17 } \\
\text {-Suppressive effect on Treg cells }\end{array}$ \\
\hline IL-27 & $\mathrm{IL}-12$ & $\begin{array}{l}\text { Heterodimer composed of two } \\
\text { subunits (EBI-3 and p28) }\end{array}$ & Antigen Presenting Cells & $\begin{array}{l}\text {-Pro-inflammatory: Differentiation of CD4 cells in Th1 } \\
\text {-Anti-inflammatory: } \\
\text {-Suppression of IL-2, IL-6 and IL-17 } \\
\text {-Reduced differentiation of CD4 cells in Th17 } \\
\text {-CD8 T cell antitumor functions } \\
\text {-B cell differentiation and immunoglobulin production } \\
\text {-Suppression of ROS production by macrophages and neutrophils } \\
\text {-Inhibition of DC maturation }\end{array}$ \\
\hline IL-33 & $\mathrm{IL}-1$ & $\begin{array}{l}\text { Pro-form: } 30 \mathrm{kDa} \\
\text { Mature form: } 18 \mathrm{kDa}\end{array}$ & $\begin{array}{l}\text { Smooth muscle cells, } \\
\text { epithelial cells, fibroblasts, } \\
\text { keratynocytes, dendritic cells } \\
\text { and activated macrophages }\end{array}$ & $\begin{array}{l}\text {-Release of Th2 cytokines (IL-5 and IL-13) } \\
\text {-Suppression of IFN-y production } \\
\text {-Induction of a Th2 response } \\
\text {-Chemoattractant for Th2 cells } \\
\text {-Differentiation of CD34+ precursor cells in mast cells } \\
\text {-Release of TNF- } \alpha, \text { IL-1 } \beta \text {, IL- } 6 \text { and MCP- } 1 \text { from bone marrow derived mast cells }\end{array}$ \\
\hline
\end{tabular}

Table I. Summary of the cellular distribution and biological function of the indicated cytokines. 


\begin{tabular}{|c|c|c|c|}
\hline Designation & Receptor family & Components & Cellular/tissue distribution \\
\hline IL-15 & IL-2R & $\begin{array}{l}\text { Heterodimer (same IL-2R } \beta \text { and } \gamma \text { chain, different } \\
\alpha \text { chain) }\end{array}$ & $\begin{array}{l}\text { Monocytes, macrophages, dendritic cells, } \\
\text { neutrophils and T cells }\end{array}$ \\
\hline IL-17 & IL-17R & $\begin{array}{l}\text { Homodimer (single a chain: IL-17RA) or } \\
\text { heterodimer (IL-17RA/IL-17RC) }\end{array}$ & $\begin{array}{l}\text { CD4 and CD8 T cells, gd T cells, NK cells, } \\
\text { monocytes and neutrophils } \\
\text { Lung, kidney, liver and spleen }\end{array}$ \\
\hline IL-18 & IL-18R & Heterodimer ( $\alpha$ and $\beta$ chain) & $\begin{array}{l}\text { Neutrophils, macrophages, basophils, mast cells, } \\
\text { naïv T cells, Th1 cells, B cells, endothelial cells, } \\
\text { smooth muscle cells, epithelial cells, synovial } \\
\text { fibroblasts and chondrocytes }\end{array}$ \\
\hline IL-21 & II-21R & Heterodimer ( $\alpha$ and $\gamma$ chain) IL-21Ra & $\begin{array}{l}\text { NK cells, } T \text { and } B \text { cells, dendritic cells, macrophages } \\
\text { and keratinocytes } \\
\text { Spleen and thymus }\end{array}$ \\
\hline IL-22 & $\mathrm{IL}-22 \mathrm{R}$ & $\begin{array}{l}\text { Homodimer (IL-22R1) or heterodimer (IL-22R1 } \\
\text { and IL-10R2) }\end{array}$ & $\begin{array}{l}\text { Epithelial cells of the gastrointestinal tract, pancreas, } \\
\text { liver, kidney and skin } \\
\text { CD4 and CD8 T cells, NK T cells, } \gamma \delta \mathrm{T} \text { cells, mast } \\
\text { cells, NK and CD } 11 \mathrm{c}^{+} \text {cells }\end{array}$ \\
\hline IL-23 & $\mathrm{IL}-12 \mathrm{R}$ & Heterodimer IL-12R $\beta 1$ and IL-23R & $\begin{array}{l}\text { Monocytes, activated APC, } \mathrm{T} \text { cells, B cells, } \\
\text { endothelial cells, microglia and Paneth cells }\end{array}$ \\
\hline IL-27 & IL-27R & $\begin{array}{l}\text { gp130 signal transducing chain of IL-6 receptor } \\
\text { and IL-27ra (WSX-1, TCCR) }\end{array}$ & $\begin{array}{l}\text { Neutrophils, monocytes, mast cells, T, B and NK } \\
\text { cells }\end{array}$ \\
\hline IL-33 & IL-1R & $\begin{array}{l}\text { Homodimer (ST2) or heterodimer (ST2 and IL- } \\
\text { 1RAcP) }\end{array}$ & Mast cells and Th2 cells \\
\hline
\end{tabular}

Table II. Summary of the indicated cytokine receptors and their cellular distribution 